\title{
Agenda intermedialna a agenda ,rzeczywista". Nieadekwatność hierarchii newsów w mediach informacyjnych do wskaźników świata rzeczywistego podczas samorządowej kampanii wyborczej w 2014 roku
}

Streszczenie: Ustanawianie agendy intermedialnej (intermedia agenda-setting), to nowy i rzadko spotykany nurt badań w ramach teorii agenda-setting. Zjawisko to polega na transferze ważności kwestii z jednego rodzaju agendy medialnej do agendy innego rodzaju (np. z agendy prasowej do telewizyjnej). Celem opracowania jest oparta na teorii i metodologii ustanawiania agendy obserwacja agendy prasowej i telewizyjnej w wybranym okresie (kampania przed wyborami do samorządu lokalnego w Polsce w 2014 r.), jak również konfrontacja hierarchii newsów tworzonych przez różne rodzaje mediów oraz wskaźników świata rzeczywistego, które tworzą tzw. agendę „rzeczywistą” (m.in. dane statystyczne dotyczące aktualnego społeczno-gospodarczego znaczenia kwestii relacjonowanych w mediach informacyjnych). Analiza materiału porównawczego pozwoli na przybliżone określenie adekwatności ważności kwestii medialnych w stosunku do nasilenia czynników świata rzeczywistego (w analizowanym okresie: 19 września-15 października 2014 r.). Efektem analizy ma być próba odpowiedzi na pytanie o zakres odzwierciedlenia złożoności świata rzeczywistego w wybranych przekazach medialnych.

Słowa kluczowe: agenda-setting, agenda intermedialna, agenda czynników świata rzeczywistego, media informacyjne

$\mathbf{U}$ stanawianie agendy intermedialnej (intermedia agenda-setting), to nowy i rzadko spotykany nurt badań w ramach teorii agenda-setting. Ustanawianie agendy intermedialnej polega na transferze ważności kwestii z jednego rodzaju agendy medialnej do agendy innego rodzaju (np. z agendy prasowej do telewizyjnej; Dearing, Rogers, 1996, s. 34). W literaturze wskazuje się na kilka przyczyn zachodzenia takiego transferu, czy przenoszenia się ważności tematów - newsów pomiędzy agendami medialnymi (Vlienenthart, Walgrave, 2008, s. 860-877). Przede wszystkim 
chodzi o stosowanie tych samych, czy podobnych kryteriów newsa przez dziennikarzy z różnych mediów. Oprócz tego, konkurencyjność środowiska medialnego powoduje, że nieuwzględnienie newsa w danej agendzie, który został już zauważony przez inne tytuły czy stacje, sprawia, że medium pozostaje w tyle i powstaje wrażenie „nienadążania”. Najbardziej istotne społecznie są jednak konsekwencje takiego zjawiska, ponieważ kiedy poszczególne media zajmują się generalnie tymi samymi problemami, które często mają tylko pozory społecznej ważności, inne kwestie i problemy muszą być siłą rzeczy pomijane, a tym samym publiczność nie ma świadomości ich istnienia lub faktycznej wagi. Ten rodzaj medialnego skrzywienia (media bias) poprzez koncentrowanie uwagi na jednych sprawach kosztem innych (niekiedy istotniejszych, o większym znaczeniu społecznym), a więc także pomijanie, odciąganie uwagi, jest rzadko szerzej analizowany, również w polskich warunkach. Celem opracowania jest oparta na teorii i metodologii ustanawiania agendy obserwacja agendy prasowej i telewizyjnej w wybranym okresie (kampania przed wyborami do samorządu lokalnego w Polsce w 2014 r.), jak również konfrontacja hierarchii newsów tworzonych przez różne rodzaje mediów oraz wskaźników świata rzeczywistego, które tworzą tzw. agendę „rzeczywistą” (m.in. dane statystyczne dotyczące aktualnego społeczno-gospodarczego znaczenia kwestii relacjonowanych w mediach informacyjnych). Analiza materiału porównawczego pozwoli na przybliżone określenie adekwatności ważności kwestii medialnych w stosunku do nasilenia czynników świata rzeczywistego (w analizowanym okresie: 19 września-15 października 2014 r.). Efektem analizy ma być próba odpowiedzi na pytanie o zakres odzwierciedlenia złożoności świata rzeczywistego w wybranych przekazach medialnych.

\section{Podstawy teoretyczne}

Teoria ustanawiania agendy jest szeroko znana uczonym na całym świecie i często jest przedmiotem operacjonalizacji w badaniach dotyczących różnorodnych zjawisk z zakresu komunikacji społecznej, a w szczególności medialnej i politycznej (McCombs, 2008; McCombs, 2014). Przedmiotem studiów agenda-setting są relacje i wzajemny wpływ świata mediów, polityki i opinii publicznej. W ramach nowych kierunków badań poszukuje się nieodkrytych dotychczas zależności, na przykład między różnymi typami mediów i subagendami medialnymi (telewizja-prasa, 
telewizja-Internet itd.). Obserwuje się relacje między agendą protestów i demonstracji a agendą mediów i agendą parlamentu oraz między agendą mediów a agendą czynników świata rzeczywistego (Walgrave, Vliegenthart, 2012, s. 129-156). Studia te mają na celu odkrywanie i wyjaśnianie skomplikowanych współzależności zachodzących pomiędzy podmiotami tworzącymi środowisko medialno-polityczne.

Ustanawianie agendy intermedialnej (inter-media agenda-setting), to zjawisko, w którym agenda medialna wpływa na agendę medialną, to jest gdzie różne kanały komunikowania medialnego relacjonują te same kwestie. Inter-media agenda-setting polega na transferze ważności kwestii $z$ jednego rodzaju agendy medialnej do agendy medialnej innego rodzaju. Agendą intermedialną są zatem wzajemne wpływy, zależności i relacje różnych mediów masowych (McCombs, 2008, s. 116; Sweetser, Golan, Wanta, 2008, s. 199). Chodzi w szczególności nie tyle o przypadki, kiedy na przykład telewizyjne programy informacyjne i prasa codzienna korzystają z tych samych doniesień agencji prasowych, ale raczej o te zjawiska, kiedy programy te korzystają z relacji prasowych, albo doniesień portali internetowych, jako podstawowego źródła informacji. Jeden z najbardziej znanych i dobrze udowodnionych przykładów ustanawiania agendy intermedialnej wskazuje na „New York Times” jako lidera agendy medialnej w Stanach Zjednoczonych (Sweetser, Golan, Wanta, 2008, s. 198-199). Dziennik ten uzyskuje istotny wpływ na tematy relacjonowane przez pozostałe media w tym państwie. W innych studiach znaleziono dowody na wpływ agendy prasowej na telewizyjną, prasy ogólnokrajowej na lokalna, agendy tematów reklam politycznych na agendę mediów informacyjnych oraz agendy informacyjnych mediów tradycyjnych na agendę informacyjnych mediów internetowych (Sweetser, Golan, Wanta, 2008, s. 199; Protess, McCombs, 1991, s. 7-20; Roberts, McCombs, 1994, s. 249).

Za podstawowe dla przedmiotu badań, jakim jest agenda intermedialna uznaje się prace M. McCombsa (2008) oraz J. W. Dearinga i E. M. Rogersa $(1988,1996)$. M. McCombs używając metafory cebuli, przedstawiającej wielowarstwową budowę otoczenia wpływającego na agendę danego medium, sytuuje inne media w środkowej części tej struktury.

Oznacza to, że o hierarchii newsów w gazecie, telewizji, czy na portalu internetowym decydują: źródła informacyjne, inne media informacyjne oraz normy regulujące tworzenie informacji (tzw. kryteria newsa; Schulz, 2006, s. 47). Czynniki świata rzeczywistego, to jest zdarzenia lub zachowania ludzkie, które mają miejsce w realnym świecie, należy uznać za składnik pierwszej, najbardziej zewnętrznej warstwy, ponieważ 




Rys. 1. Metaforyczna „cebula” - kształtowanie agendy mediów

Źródło: Opracowanie własne na podstawie: M. McCombs, Ustanawianie agendy. Media masowe i opinia publiczna, Wydawnictwo Uniwersytetu Jagiellońskiego, Kraków 2008, s. 119.

tylko część z tych czynników pracownicy określonej redakcji są w stanie zaobserwować bezpośrednio (reporterzy), a większość z nich dociera do redakcji czy newsroomu z innych źródeł (są filtrowane przez inne źródła informacyjne, np. doniesienia agencji prasowych i agend rządowych lub innych instytucji). To zewnętrzne usytuowanie wskaźników świata rzeczywistego tłumaczy także trudności z ich przedostaniem się do agendy mediów. Dodatkową „zaporą" mogą być kryteria wartości newsa, np. negatywizm, związek z narodem elitarnym lub określoną osobą - członkiem elit. Jeśli przykładowo informacja o spadku poziomu inflacji publikowana przez instytucje finansowe nie przejdzie przez „sito” kryteriów newsa, wówczas nie stanie się częścią agendy medialnej tworzonej przez najpopularniejszych nadawców.

J. W. Dearing i E. M. Rogers uważają, że na agendę mediów wpływają przede wszystkim następujące determinanty: społeczne czynniki strukturalne, czynniki świata rzeczywistego, spektakularne wydarzenia, decyzyjni dziennikarze (gatekeepers) i wpływowe media (Dearing, Rogers, 1988, s. 555-594). Można je podzielić na dwie grupy. Pierwsza z nich obejmuje czynniki świata rzeczywistego, społeczne czynniki strukturalne 
i spektakularne wydarzenia. Elementy te w różny sposób odzwierciedlają stan i dynamikę realnego świata i są definiowane przez wskaźniki statystyczne (dotyczące gospodarki, społeczeństwa, kultury itd.), strukturę relacji społecznych (np. reprezentacje interesów elit społecznych) oraz wyjątkowe zdarzenia, tzw. focussing events (Birkland, 2007, s. 17; np. katastrofy naturalne, wypadki, przestępstwa, nietypowe zachowania ludzkie i inne wydarzenia i działania wywołujące skutki w wielkiej skali lub o istotnym znaczeniu dla członków krajowych lub światowych elit społecznych). Druga grupa czynników, czy raczej podmiotów, to decyzyjni dziennikarze i wpływowe media. Wpływ tych podmiotów na agendę intermedialną jest determinowany przez wartość informacyjną wiadomości - kryteria newsa. W literaturze funkcjonuje co najmniej kilka różnych „zestawów” kryteriów newsa, a poszczególni badacze kładą nacisk na zróżnicowane wartości informacyjne. Za klasyczną uchodzi typologia kryteriów newsa zaproponowana przez J. Galtunga i M. H. Ruge w studium z 1965 r. (s. 64-90). Zawiera ona następujące cechy: negatywizm, bliskość geograficzna i zrozumiałość społeczno-kulturowa, związek z elitami, klarowność, przekroczenie progu znaczenia, zaskoczenie, kontynuacja, personalizacja, komplementarność, zgodność z normami i zwyczajami produkcji newsów w danej organizacji medialnej. Im więcej tych kryteriów jest wypełnianych przez dane wydarzenie, tym większa szansa, że stanie się ono newsem. W. Schulz wymienia bardzo podobne kryteria, wskazując jednakże na istotne znaczenie emocjonalnego ładunku informacji, zawierającego agresję, kontrowersyjność, zagrożenie dla wartości lub pokazującego wyjątkowy sukces (Schulz, 2006, s. 47).

Agenda intermedialna według J. W. Dearinga i E. M. Rogersa przejawia się $\mathrm{w}$ dwóch wymiarach. Po pierwsze, poprzez podobieństwo agend różnych środków przekazu (te same informacje uzyskują ważność i wchodzą do agendy), po drugie, przez podobieństwo hierarchii newsów w ramach agend różnych mediów (te same informacje są prezentowane w tej samej lub podobnej hierarchii; Dearing, Rogers, 1988, s. 34). Jako jeden z przekonujących dowodów przytaczają wyniki badań prowadzonych przez J. W. Rogersa i S. Changa dotyczące relacji na temat głodu w Etiopii (Rogers, Chang, 1991). Obserwacje te wskazywały, że w przekazie trzech opiniotwórczych dzienników amerykańskich („New York Times”, „Los Angeles Times”, ,Washington Post”) oraz trzech kanałów telewizyjnych (ABC, CBS, NBC) w listopadzie 1984 r. nastąpił jednoczesny gwałtowny wzrost uwagi dotyczącej klęski głodu w Etiopii. Wzrost medialnej uwagi był oczywiście związany z nasileniem się problemu gło- 
du wskutek suszy, ale bezpośrednią przyczyną wzrostu zainteresowania był 3,5 minutowy film wyemitowany przez stację NBC, w sposób sugestywny, a nawet przerażający przedstawiający głodujące dzieci.

Studium oparte na szerokim zakresie źródeł powstało w Stanach Zjednoczonych w latach 1995-2000 (Golan, 2006, s. 326-331). Analizą objęto trzy stacje telewizyjne (ABC, NBC, CBS) oraz dziennik „New York Times". Obserwowano intermedialną agendę informacji dotyczących spraw międzynarodowych. Wyniki badań wskazały kierunek wpływu - agenda prasowa miała istotne znaczenie dla ustanawiania hierarchii tematów w telewizyjnych programach informacyjnych trzech stacji. Wydaje się jednakże, że te wyniki nie mogą być bezpośrednio odnoszone do innych systemów medialnych, gdzie pozycja nawet opiniotwórczej prasy również może nie być równie wysoka, a na pewno jej wpływ na inne rodzaje mediów informacyjnych wymagałby weryfikacji badawczej. Należy także zwrócić uwagę na wyjątkowe znaczenie opiniotwórcze znaczenie dziennika „New York Times”, którego pozycja jest bardzo wysoka także poza USA.

Podsumowując rozważania dotyczące agendy intermedialnej, należy także wskazać na konsekwencje tego zjawiska. Przede wszystkim istotne znaczenie ma sprawa zajmowania się generalnie tymi samymi sprawami przez różne media informacyjne. Jeżeli tak się dzieje, to inne, równie ważne lub nawet ważniejsze problemy muszą być siłą rzeczy pomijane. Po drugie, skoro stacje i redakcje mediów, podejmując decyzje o publikacji, kierują się tymi samymi kryteriami newsa, gdzie na pierwszym planie jest medialna atrakcyjność materiału (dominacja przyjemności odbiorczej i stymulacji emocjonalnej, jako głównego założenia, czy motywacji tworzenia relacji nadawczo-odbiorczych w mediach w ogóle, niezależnie od tematyki i form dyskursu; M. Lisowska-Magdziarz, 2014, s. 51), a społeczna istotność problemu nie jest głównym czynnikiem determinującym te decyzje, to publiczność nie ma świadomości istnienia lub faktycznej wagi wielu mających miejsce wydarzeń, procesów i ich konsekwencji. Po trzecie, poprzez tworzenie określonej, generalnie wspólnej dla większości mediów mainstreamowych, agendy tematów dostępnych w danym czasie odbiorcom, tworzone są pozory społecznej ważności tych tematów, a zatem dochodzi, czy może dochodzić, do rodzaju skrzywienia czy medialnej manipulacji, która następuje $\mathrm{w}$ różnym zakresie $\mathrm{w}$ różnym czasie $\mathrm{i}$ co do zróżnicowanych zjawisk (Herman, Chomsky, 1988, s. XVI-XVIII). Najczęściej nie jest to skrzywienie świadome, jest ono trudne do uniknięcia (pracownicy 
mediów nie są w stanie zrelacjonować wszystkich istotnych społecznie wydarzeń w danym czasie, ale też nie zawsze do tego dążą) i skomplikowana badawczo, ze względu na wielość, a niekiedy niedostępność źródeł określających czynniki świata rzeczywistego.

\section{Agenda „rzeczywista” (agenda czynników świata rzeczywistego)}

Szczególny rodzaj agendy (złożonej z wielu subagend) tworzą tzw. czynniki świata rzeczywistego (real world factors) odzwierciedlające faktyczny poziom nasilenia danego problemu (np. przykład poziom bezrobocia czy przestępczości). Przedstawiane są one w formie wskaźników liczbowych i publikowane przez instytucje i organizacje zajmujące się określoną polityką publiczną lub danym problemem (np. urzędy statystyczne, ministerstwa, organizacje pozarządowe). Real world factor jest to pojedynczy czynnik (subagenda) lub kompleks czynników określających znaczenie lub nasilenie danego problemu społecznego (Dearing, Rogers, 1996, s. 34). Na przykład głównym czynnikiem świata rzeczywistego dla problemu bezrobocia jest wskaźnik statystyczny określający poziom bezrobocia. Natomiast w przypadku problemu zanieczyszczenia środowiska konieczne jest przedstawienie szeregu danych określających np. zanieczyszczenie atmosfery czy wód przez różne substancje, bakterie i mikroorganizmy.

Czynniki świata rzeczywistego, choć rzadko, to jednak były przedmiotem studiów agenda-setting. Prawdopodobnie za pierwsze tego rodzaju studium należy uznać pracę G. R. Funkhousera z 1973 r. (s. 62-75), w której empirycznie dowiódł on, że agenda mediów informacyjnych ma niewiele wspólnego ze wskaźnikami świata rzeczywistego. W innej pracy z 1990 r. G. R. Funkhouser i E. F. Shaw (s. 75-87) formułują tezę, że media mają zdolność do kreowania sztucznych wydarzeń i sztucznych doświadczeń wśród odbiorców, które są jednak przez nich traktowane i przeżywane jak prawdziwe. Autorzy proponują także koncepcję micro i macro agenda-setting. Micro agenda-setting to zdolność mediów informacyjnych do wpływania na sposób oceny znaczenia i treści określonych kwestii poprzez nacisk na odpowiednie problemy i ich wymiary, zaś $m a-$ cro agenda-setting, to możliwość wpływania przez media na generalny sposób odbioru świata rzeczywistego poprzez uatrakcyjnianie, tendencyjność, powiększanie lub pomniejszanie wagi wydarzeń i kwestii. Działania te są planowane w taki sposób, aby realizować interesy mediów 
jako biznesu. Wnioski z analiz sugerują, że nie tylko media informacyjne nie odzwierciedlają świata rzeczywistego, ale w sztuczny sposób kreują nasze oczekiwania i kształtują nasze otoczenie (na przykład poprzez obniżanie tolerancji na niski poziom aktywności i naturalną nudę, zawyżone oczekiwania wobec otoczenia i nadmierne dążenie do perfekcyjności, wymaganie szybkich efektywnych rozwiązań skomplikowanych problemów, fałszywą percepcję niektórych typów zdarzeń, m.in. z zastosowaniem przemocy, ograniczony kontakt lub zniekształcony obraz bezpośredniego środowiska, w którym żyjemy, m.in. z powodu rosnącej ilości czasu spędzanego w towarzystwie mediów elektronicznych; Funkhouser, Shaw, 1990, s. 85-86).

W pracy W. Kingdona (1984, s.77) real world factor jest składnikiem tzw. window of opportunity, to jest sytuacji, kiedy otwiera się szansa na zmianę kursu danej polityki publicznej. Na okno szansy składa się także wiele innych czynników, m.in. układ sił na scenie politycznej, stosunek opinii publicznej do problemu, ale warunki obiektywne również stanowią istotną przesłankę przemawiającą za lub przeciwko zmianie. Długoterminowe studia wskazują jednakże, że kiedy następuje istotna zmiana w zakresie kierunku polityki publicznej, najczęściej występuje ona wówczas, kiedy czynniki świata rzeczywistego wchodzą w interakcję z opinią publiczną (Jones, Baumgartner, 2005, s. 211; Gava, Giugni, Varone, 2013, s. 194). Zmiana w obrębie jednego $\mathrm{z}$ aspektów świata rzeczywistego jest zauważana i uznana za istotną przez opinię publiczną najczęściej dopiero dzięki pośrednictwu mediów.

Badania prowadzone w latach 90-tych XX w. wskazały na negatywna korelację czynników świata rzeczywistego oraz relacji medialnych dotyczących ekologii w Stanach Zjednoczonych. Większa intensywność relacji medialnych dotycząca problemów ekologicznych nie była wynikiem większego nasilenia tych problemów lecz innych, pozaekologoicznych determinantów (Dearing, Rogers, 1996, s. 28). W studium B. D. Jonesa i F. R. Baumgartnera dotyczącym polityki gospodarczej USA obserwowano zainteresowanie problematyką ekonomiczną wśród członków Kongresu i opinii publicznej (badania dotyczyły okresu: 1946-1998). Sekwencja wzrostu zainteresowania była następująca: najpierw pojawiało się zwiększone zainteresowanie ze strony kongresmenów, następnie pojawiały się sondaże opinii publicznej wskazujące, że kwestie te mają wysoki priorytet ważności, a dopiero później niejako potwierdzały to wskaźniki świata rzeczywistego (Jones, Baumgartner, 2005, s. 212-213). Oznacza to, że społeczna ważność kwestii, w tym przypadków proble- 
mów gospodarczych, może być zwiększana lub ograniczana w sposób sztuczny i w oderwaniu od faktycznych warunków.

Można znaleźć w literaturze także inne przykłady, na to, że medialna ważność kwestii ma niewiele wspólnego z czynnikami świata rzeczywistego, determinantami społecznymi, a nawet spektakularnymi wydarzeniami, a najbardziej na tę ważność wpływa uwaga innych mediów poświęcona danemu problemowi. Taką sprawą była w latach 80-tych XX w. w Stanach Zjednoczonych tzw. sprawa uzależnienia od kokainy, którą media przedstawiały jako „epidemię”, chociaż poziom „spożycia” tego narkotyku był na relatywnie stałym poziomie od lat 70-tych (Danielian, Reese, 2009, s. 47).

S. N. Soroka formułuje i pozytywnie weryfikuje tezę, że poszczególne kwestie - polityki mogą być bardziej lub mniej „wrażliwe” na czynniki świata rzeczywistego, media lub zależeć od samych polityków (Soroka, 2002, s. 97). Na przykład na politykę wobec bezrobocia i inflacji w relatywnie największym stopniu wpływają czynniki świata rzeczywistego, natomiast relacje medialne na ten temat, a w konsekwencji także reakcje opinii publicznej są raczej pochodną faktycznych zmian. Bardziej wrażliwa na wpływ mediów (jak już wyżej wspomniano) jest polityka ochrony środowiska. Z kolei polityka finansowa (np. dotycząca deficytu budżetowego) jest domeną samych polityków - decydentów i pozostaje najbardziej niezależna od wpływu mediów, chociaż oczywiście i w tym przypadku decydującą rolę mogą odgrywać czynniki świata rzeczywistego.

Znaczenie czynników świata rzeczywistego polega na tym, że ich uwzględnianie w badaniach dotyczących agendy medialnej lub intermedialnej pozwala na weryfikację, w jakim zakresie zmiany dotyczące uwagi mediów, poświęconej określonym tematom, spowodowane są rzeczywistym nasileniem się lub powstaniem określonych problemów w otoczeniu społecznym, ekonomicznym lub politycznym, a na ile są one związane $\mathrm{z}$ nagłaśnianiem danego problemu $\mathrm{w}$ innych mediach, to jest $\mathrm{z}$ naśladownictwem medialnym. Studia dotyczące tego tematu dają szansę na eksplorację istotnego problemu z zakresu funkcjonowania mediów informacyjnych, to jest form i zakresu kreowania rzeczywistości poprzez produkcję i publikację informacji w środkach przekazu. Zadanie to jest rodzajem wyzwania badawczego, ponieważ ten nurt badań agenda-setting, w którym porównuje się agendy medialne i agendy czynników świata rzeczywistego nie wypracował jeszcze sprawdzonych procedur. Dlatego też poniższa analiza zgromadzonych danych ma charakter eksploracyjny. 


\section{Material empiryczny i metody badań}

Materiał empiryczny poddany analizie porównawczej składa się z dwóch zasadniczych części. Pierwszą z nich tworzy agenda czynników świata rzeczywistego - agenda ,rzeczywista” (real world factors agenda), zaś drugą agenda medialna, złożona z kolei z agendy prasowej i telewizyjnej. Celem analizy jest określenie adekwatności ważności kwestii medialnych w stosunku do nasilenia czynników świata rzeczywistego - konfrontacja hierarchii newsów tworzonych przez różne rodzaje mediów oraz wskaźników świata rzeczywistego. Agenda medialna zawiera następujące dane: agenda prasowa, to prezentowane każdego dnia jako trzy pierwsze newsy - wiadomości w internetowych wydaniach dzienników „Rzeczpospolita” i „Gazeta Wyborcza”, w okresie 19 września-15 października 2014 r. (rejestracja o różnych porach dnia); agenda telewizyjna, to prezentowane każdego dnia jako trzy pierwsze newsy w głównych wydaniach telewizyjnych audycji informacyjnych - „Fakty” i „Wiadomości” w okresie 19 września-15 października 2014 r. Łącznie zarejestrowano i zakodowano ponad 300 newsów. Jako listę kodów wykorzystano dostosowaną do polskich warunków wersję międzynarodowej książki kodowej utworzoną i stosowaną w badaniach agenda-setting w Europie i USA: List of Major Topic Codes - lista kodów tematów głównych - Comparative Agendas Project (2014). Agendę czynników świata rzeczywistego tworzą wskaźniki zawarte w raporcie: OECD Economic Surveys: Poland 2014, Assesment and Recomendations (OECD 2014, s. 19-30).

Analiza danych składa się z dwóch części. Po pierwsze, jest to analiza porównawcza zestawu kwestii w agendzie prasowej i telewizyjnej, a jej wynikiem jest ustalenie hierarchii kwestii w obydwu agendach medialnych, a następnie zakresu spójności agendy prasowej i telewizyjnej i określenie zawartości i hierarchii kwestii w agendzie intermedialnej. Druga część obserwacji badawczej polega na ustaleniu hierarchii kwestii w agendzie czynników świata rzeczywistego oraz analizie porównawczej agendy intermedialnej i agendy czynników świata rzeczywistego, a następnie na wyciaganiu wniosków na temat konsekwencji ustanawiania agendy intermedialnej. Bezpośrednim celem badania jest weryfikacja dwóch głównych hipotez:

H1: Transfer kwestii pomiędzy subagendami medialnymi (prasowo-internetową i telewizyjną) występuje w stopniu istotnym (ta sama kwestia w obydwu subagendach uzyskuje udział powyżej 5 proc.); 
H2: Transfer kwestii z agendy czynników świata rzeczywistego do agendy intermedialnej nie występuje w stopniu istotnym (problemy świata rzeczywistego nie znajdują relewantnego odzwierciedlenia w agendzie medialnej; ta sama kwestia nie uzyskuje udziału powyżej 5 proc. w agendzie intermedialnej i agendzie czynników świata rzeczywistego).

Tabela 1

Agenda prasowa - ranking według liczby newsów

\begin{tabular}{|c|c|c|c|}
\hline Lp. & Temat - przedmiot relacji medialnych & $\begin{array}{l}\text { Liczba } \\
\text { relacji me- } \\
\text { dialnych }\end{array}$ & $\begin{array}{l}\text { Udzial } \\
\text { procen- } \\
\text { towy }\end{array}$ \\
\hline 1. & Prawo, przestępstwa, sądy & 27 & 17,6 \\
\hline 2. & Ludzie, rozmaitości, inne & 23 & 15,0 \\
\hline 3. & $\begin{array}{l}\text { Administracja centralna i lokalna, kampanie wyborcze, wy- } \\
\text { borcze i konstytucyjne, proces legislacyjny, nominacje do } \\
\text { urzędów i sądów }\end{array}$ & 19 & 12,4 \\
\hline 4. & Kościoły i religie & 9 & 5,9 \\
\hline 5. & Prawa człowieka, mniejszości, wolności osobiste & 7 & 4,6 \\
\hline 6. & Obronność & 7 & 4,6 \\
\hline 7. & Sprawy zagraniczne i akcje humanitarne & 7 & 4,6 \\
\hline 8. & Zatrudnienie, praca, migracje na rynkach pracy & 6 & 3,9 \\
\hline 9. & Finanse, banki, handel wewnętrzny & 6 & 3,9 \\
\hline 10. & $\begin{array}{l}\text { Przedsięwzięcia i inwestycje państwowe i ich finansowanie } \\
\text { przez budżet państwa, infrastruktura }\end{array}$ & 5 & 3,3 \\
\hline 11. & Sport i rekreacja (turystyka) & 5 & 3,3 \\
\hline 12. & Ochrona zdrowia & 4 & 2,6 \\
\hline 13. & Edukacja & 4 & 2,6 \\
\hline 14. & Transport & 4 & 2,6 \\
\hline 15. & Problemy społeczności lokalnych i gospodarstw domowych & 4 & 2,6 \\
\hline 16. & Nauka, technologia, komunikacja, przestrzeń kosmiczna & 4 & 2,6 \\
\hline 17. & Sztuka i rozrywka & 4 & 2,6 \\
\hline 18. & Śmierć (znane osoby) & 4 & 2,6 \\
\hline 19. & Makroekonomia/problemy gospodarcze & 2 & 1,3 \\
\hline 20. & Energia & 1 & 0,7 \\
\hline \multirow[t]{2}{*}{21.} & Pogoda i katastrofy naturalne & 1 & 0,7 \\
\hline & Razem & 153 & 100,00 \\
\hline
\end{tabular}

Źródło: Opracowanie własne. 
Agenda telewizyjna - ranking według liczby newsów

Tabela 2

\begin{tabular}{|r|l|c|r||}
\hline Lp. & \multicolumn{1}{|c|}{ Temat - przedmiot relacji medialnych } & $\begin{array}{c}\text { Liczba } \\
\text { relacji me- } \\
\text { dialnych }\end{array}$ & $\begin{array}{c}\text { Udzial } \\
\text { procen- } \\
\text { towy }\end{array}$ \\
\hline 1. & $\begin{array}{l}\text { Administracja centralna i lokalna, kampanie wyborcze, } \\
\text { wyborcze i konstytucyjne, proces legislacyjny, nominacje } \\
\text { do urzędów i sądów }\end{array}$ & 36 & 22,8 \\
\hline 2. & Sprawy zagraniczne i akcje humanitarne & 20 & 12,7 \\
\hline 3. & Prawo, przestepstwa, sądy & 14 & 8,9 \\
\hline 4. & Pogoda i katastrofy naturalne & 14 & 8,9 \\
\hline 5. & Sport i rekreacja (turystyka) & 11 & 7,0 \\
\hline 6. & Zatrudnienie, praca, migracje na rynkach pracy & 10 & 6,3 \\
\hline 7. & Finanse, banki, handel wewnętrzny & 8 & 5,1 \\
\hline 8. & Ludzie, rozmaitości, inne & 8 & 5,1 \\
\hline 9. & Prawa człowieka, mniejszości i wolności osobistych & 7 & 4,4 \\
\hline 10. & Obronność & 7 & 4,4 \\
\hline 11. & Kościoły i religie & 7 & 4,4 \\
\hline 12. & Ochrona zdrowia & 5 & 3,2 \\
\hline 13. & Śmierć (znane osoby) & 3 & 1,9 \\
\hline 14. & Makroekonomia/problemy gospodarcze & 2 & 1,3 \\
\hline 15. & Energia & 1 & 1,3 \\
\hline 16. & Sztuka i rozrywka & 1 & 0,6 \\
\hline 17. & Problemy społeczności lokalnych i gospodarstw domowych & 1 & 0,6 \\
\hline 18. & Transport & 1 & 0,6 \\
\hline 19. & Edukacja & 158 & 0,6 \\
\hline & Razem & & 100,00 \\
\hline
\end{tabular}

Źródło: Opracowanie własne.

Biorąc pod uwagę zaproponowany w hipotezach próg istotności na poziomie 5 proc. (jest to próg umowny przyjęty dla badawczych celów eksploracyjnych) uzyskujemy osiem tematów/kwestii, które przekroczyły ten próg w agendzie telewizyjnej, cztery tematy/kwestie w agendzie internetowo-prasowej oraz trzy tematy wspólne w obydwu subagendach. Są to następujące tematy: Prawo, przestępstwa, sądy; Ludzie, rozmaitości, inne; Administracja centralna i lokalna, kampanie wyborcze, wyborcze i konstytucyjne, proces legislacyjny, nominacje do urzędów i sądów. Spośród tych trzech tematów największą spójność analizowane subagendy medialne osiągnęły w zakresie kwestii: Prawo, przestępstwa, sądy, ponieważ różnica pomiędzy udziałem procentowym tej kwestii w agendzie telewizyjnej i prasowej była relatywnie najmniejsza ( 8,7 proc.). Nieco mniejsza spójność daje się zaobserwować dla tematu: Ludzie, rozmaitości, inne (różni- 
ca 9,9 proc.) oraz dla tematu: Administracja centralna i lokalna, kampanie wyborcze, wyborcze i konstytucyjne, proces legislacyjny, nominacje do urzędów i sądów (różnica 10,4 proc.). Obserwacje te potwierdzają hipotezę o istotnej spójności agend, a także dotychczasowe ustalenia zawarte w literaturze przedmiotu, a dotyczące stosowania wspólnych kryteriów newsa, wśród których medialna atrakcyjność i sensacyjność informacji odgrywa decydującą rolę. W zakresie kwestii związanych ze stosowaniem prawa i przestępczości obydwie agendy wykazują największą spójność, co może oznaczać, że niezależnie od typu medium tego rodzaju wydarzenia najłatwiej uzyskują widoczność w środkach przekazu.

Tabela 3

\section{Agenda intermedialna}

\begin{tabular}{|c|c|c|c|}
\hline Lp. & Temat - przedmiot relacji medialnych & $\begin{array}{l}\text { Liczba } \\
\text { relacji me- } \\
\text { dialnych }\end{array}$ & $\begin{array}{l}\text { Udzial } \\
\text { procen- } \\
\text { towy }\end{array}$ \\
\hline 1. & $\begin{array}{l}\text { Administracja centralna i lokalna, kampanie wyborcze, wy- } \\
\text { borcze i konstytucyjne, proces legislacyjny, nominacje do } \\
\text { urzędów i sądów }\end{array}$ & 55 & 17,68 \\
\hline 2. & Prawo, przestępstwa, sądy & 41 & 13,18 \\
\hline 3. & Ludzie, rozmaitości, inne & 31 & 9,97 \\
\hline 4. & Sprawy zagraniczne i akcje humanitarne & 27 & 8,68 \\
\hline 5. & Sport i rekreacja (turystyka) & 16 & 5,14 \\
\hline 6. & Kościoły i religie & 16 & 5,14 \\
\hline 7. & Zatrudnienie, praca, migracje na rynkach pracy & 16 & 5,14 \\
\hline 8. & Pogoda i katastrofy naturalne & 15 & 4,82 \\
\hline 9. & Prawa człowieka, mniejszości, wolności osobiste & 14 & 4,50 \\
\hline 10. & Finanse, banki, handel wewnętrzny & 14 & 4,50 \\
\hline 11. & Obronność & 14 & 4,50 \\
\hline 12. & Ochrona zdrowia & 9 & 2,89 \\
\hline 13. & Śmierć (znane osoby) & 7 & 2,25 \\
\hline 14. & Edukacja & 5 & 1,61 \\
\hline 15. & Transport & 5 & 1,61 \\
\hline 16. & Problemy społeczności lokalnych i gospodarstw domowych & 5 & 1,61 \\
\hline 17. & $\begin{array}{l}\text { Przedsięwzięcia i inwestycje państwowe i ich finansowanie } \\
\text { przez budżet państwa }\end{array}$ & 5 & 1,61 \\
\hline 18. & Infrastruktura & 5 & 1,61 \\
\hline 19. & Sztuka i rozrywka & 5 & 1,61 \\
\hline 20. & Nauka, technologia, komunikacja, przestrzeń kosmiczna & 4 & 1,29 \\
\hline 21. & Makroekonomia/problemy gospodarcze & 4 & 1,29 \\
\hline \multirow[t]{2}{*}{22.} & Energia & 3 & 0,96 \\
\hline & Razem & 311 & 100,00 \\
\hline
\end{tabular}

Źródło: Opracowanie własne. 
W tabeli 3 znajduje się zestawienie tematów/kwestii agendy intermedialnej, których hierarchia została ustalona poprzez zsumowanie udziałów tych tematów w obydwu subagendach. Ranking ten wskazuje na największą popularność informacji związanych z administracją lokalną i centralną, a w szczególności chodzi tu o kontekst wyborczy. Z jednej strony wydaje się to naturalne ze względu na trwającą w tym czasie kampanię wyborczą do samorządu lokalnego, jednakże widoczne jest także odmerytorycznienie przekazu medialnego na temat polityki, ponieważ tak istotne problemy jak: Obronność (4,50 proc. przekazu), Ochrona zdrowia $(2,89$ proc.) i Makroekonomia i problemy gospodarcze (1,29 proc.) znajdują się na odległych miejscach w rankingu.

Tabela 4

Agenda czynników świata rzeczywistego

\begin{tabular}{||l|l|c|r|}
\hline Lp. & \multicolumn{1}{|c|}{ Przedmiot rekomendacji OECD } & $\begin{array}{c}\text { Liczba } \\
\text { rekomen- } \\
\text { dacji }\end{array}$ & $\begin{array}{c}\text { Udzial } \\
\text { procen- } \\
\text { towy }\end{array}$ \\
\hline 1. & Opieka społeczna, problemy rodzin & 4 & 28,57 \\
\hline 2. & $\begin{array}{l}\text { Administracja centralna i lokalna, kampanie wyborcze, wy- } \\
\text { borcze i konstytucyjne, proces legislacyjny, nominacje do } \\
\text { urzędów i sądów }\end{array}$ & 4 & 28,57 \\
\hline 3. & Zatrudnienie, praca, migracje na rynkach pracy & 2 & 14,29 \\
\hline 4. & Skarb Państwa, instytucje państwowe, zasoby środowiskowe & 2 & 14,29 \\
\hline 5. & Makroekonomia/problemy gospodarcze & 1 & 7,14 \\
\hline 6. & Środowisko/ochrona środowiska & 1 & 7,14 \\
\hline & Razem & 14 & 100,00 \\
\hline
\end{tabular}

Źródło: Opracowanie własne na podsatwie: OECD Economic Surveys: Poland 2014, Assesment and Recomendations, OECD 2014, http://www.keepeek.com/Digital-AssetManagement/oecd/economics/oecd-economic-surveys-poland-2014/assessment-andrecommendations_eco_surveys-pol-2014-3-en\#page9, 18.10.2014, s. 19-30.

Jeszcze wyraźniej na płytkość i odmerytorycznienie dyskursu politycznego wskazuje analiza porównawcza agendy intermedialnej i agendy czynników świata rzeczywistego. Zbudowany na podstawie raportu OECD ranking najważniejszych problemów Polski (najważniejsze problemy Polski i rekomendacje OECD zakodowane zgodnie z listą kodów Comparative Agendas Project) znajduje odzwierciedlenie w rankingu agendy intermedialnej w niewielkim stopniu (OECD, 2014, s. 19-30). Najważniejsza z kwestii w Polsce to według OECD: Opieka społeczna, problemy rodzin, którym nie poświęcono ani jednej wysoko hierarchizowanej relacji medialnej w badanym okresie. Według opracowania OECD, 
do najważniejszych problemów w Polsce należą niekorzystne trendy demograficzne i obniżanie się dzietności oraz tendencje związane z faktem, że rozwój gospodarczy nie przekłada się na spadek bezrobocia. Temat drugi w rankingu OECD dotyczący administracji i wyborów znajduje się również wysoko $\mathrm{w}$ rankingu medialnym (17,68 proc.), ale głębsza analiza wskazuje, że obejmuje on inne jakościowo problemy, niż te, które były przedmiotem relacji w mediach informacyjnych. Rekomendacje OECD dotyczą przede wszystkim obniżenia kosztów oraz zwiększenia wydajności administracji publicznej. Trzeci temat, dotyczący zatrudnienia, pracy i migracji również nie należy do problemów, któremu w prasie lub telewizji poświęca się wystarczająco (proporcjonalnie do jego wagi) dużo zainteresowania (siódma pozycja w hierarchii agendy intermedialnej, 5,15 proc.). W tym zakresie rekomendacje dotyczą ograniczenia przywilejów różnych grup zawodowych, przyspieszenia obniżania wieku emerytalnego dla kobiet oraz obniżenia dostępności rent inwalidzkich jako „sposobu na życie”. Tematom tym poświęca się w polskich mediach niewiele miejsca, nie tylko ze względu na fakt, że są one skomplikowane problemowo (trudne do profesjonalnego, dziennikarskiego opracowania), ale także dlatego, że są one niepopularne, w sensie braku akceptacji ze strony opinii publicznej dla rozwiązań ograniczających świadczenia i przywileje. Problemy ekonomiczne, którym poświęcono w agendzie intermedialnej $\mathrm{w}$ badanym okresie wyjątkowo mało miejsca i czasu $(1,29$ proc.), to przede wszystkim konieczność stymulowania wzrostu dochodu obywateli poprzez obniżanie podatków i powiązanie wysokości składki na ubezpieczenie społeczne z działalności gospodarczej (samozatrudnieni) z wysokością osiaganych przychodów. Raport OECD wskazuje także nadmierny deficyt budżetowy (rekomendowany poniżej 3 proc. w 2015 r.) ${ }^{1}$ oraz na potrzebę wzrostu opodatkowania ekologicznego, dalszej prywatyzacji w konkurencyjnych sektorach gospodarki i zwiększenie ściągalności podatków.

Przedstawione wyżej wyniki analiz mają charakter wstępny i nieostateczny. Podstawowa trudność badawcza, to problem znalezienia adekwatnego źródła, na podstawie którego możnaby ustalić agendę czynników świata rzeczywistego. Zastosowany raport OECD był najbardziej aktualny dla czasu obserwacji, pochodził z marca 2014 r., i jest publikowany co dwa lata, ale do jego przygotowania zastosowano dane z wcześniejszych

1 „Przewidywania Ministerstwa Finansów na 2015 r. wskazują na możliwość obniżenia deficytu budżetowego w 2015 r. poniżej 3 proc., co przyniosłoby zdjęcie z Polski przez Komisję Europejską procedury nadmiernego deficytu" (Sejm, 2015; Minister, 2015). 
okresów, co może zaburzać ich pełną adekwatność. Dlatego też konieczne jest poszukiwanie także innych zestawów wskaźników świata rzeczywistego i korzystanie z szerszych zestawów danych medialnych. Dla celów weryfikacji ustaleń zawartych w niniejszej analizie użyteczne może być na przykład spostrzeżenie dokonane na podstawie analizy szerokiego zestawu danych medialnych (Raport, 2009-2011), choć obejmujących tylko newsy w stacjach telewizyjnych w latach 2009-2011 („Wiadomości”, „Fakty”, „Wydarzenia”, „Panorama”). Analiza tego zbioru danych wskazuje na przykład, że udział newsów o tematyce społeczno-gospodarczej w całości tematów wyniósł zaledwie 3,51 proc.

Porównując agendę intermedialną i agendę czynników świata rzeczywistego należy także brać pod uwagę odmienności natury tych agend. Natura agendy środków przekazu jest w immanentny sposób determinowana przez atrakcyjność medialną, ponieważ jest skierowana do masowego odbiorcy i przeznaczona dla (w większości) niewyrafinowanej publiczności. Nie jest także obiektywnie możliwe, aby wiadomości medialne w pełny sposób odzwierciedlały wszystkie istotnie społecznie problemy i aktualne wydarzenia. Wydaje się natomiast, że przedstawiona struktura agendy intermedialnej i wysoki stopień jej spójności (podobieństwo agendy prasowo-internetowej i telewizyjnej) utrudnia, a niekiedy uniemożliwia obywatelom dostęp do pełnego zestawu zróżnicowanych informacji, zaś wysoki stopień braku spójności agendy intermedialnej i agendy czynników świata rzeczywistego, utrudnia lub uniemożliwia dostęp do pełnego, wyczerpującego zestawu istotnych społecznie informacji².

${ }^{2}$ Zgodnie z art. 1 ustawy z 29 grudnia 1992 r. o radiofonii i telewizji: zadaniem radiofonii i telewizji jest: 1) dostarczanie informacji; 2) udostępnianie dóbr kultury i sztuki; 3) ułatwianie korzystania z oświaty, sportu i dorobku nauki; 3a) upowszechnianie edukacji obywatelskiej; 4) dostarczanie rozrywki; 5) popieranie krajowej twórczości audiowizualnej. Zgodnie z art. 21 ustawy: Programy i inne usługi publicznej radiofonii i telewizji powinny: 1) kierować się odpowiedzialnością za słowo i dbać o dobre imię publicznej radiofonii i telewizji; 2) rzetelnie ukazywać całą różnorodność wydarzeń i zjawisk w kraju i za granica; 3) sprzyjać swobodnemu kształtowaniu się poglądów obywateli oraz formowaniu się opinii publicznej. Zgodnie z art. 1 Prawa prasowego (Ustawa z dnia 26 stycznia 1984 r. Prawo prasowe), prasa, zgodnie z Konstytucją Rzeczypospolitej Polskiej, korzysta z wolności wypowiedzi i urzeczywistnia prawo obywateli do rzetelnego informowania, jawności życia publicznego oraz kontroli i krytyki społecznej; zgodnie z art. 6: Prasa jest zobowiązana do prawdziwego przedstawiania omawianych zjawisk (Art. 3 ustawy o radiofonii i telewizji stanowi, że: Do rozpowszechniania programów radiowych i telewizyjnych stosuje się przepisy prawa prasowego, o ile ustawa nie stanowi inaczej). 


\section{Konkluzje}

Biorąc pod uwagę przedstawione wyżej cele badawcze i sformułowane hipotezy, należy na podstawie zgromadzonego materiału potwierdzić hipotezę pierwszą, a częściowo także drugą: istotny stopień spójności subagend prasowo-internetowej i telewizyjnej wskazuje, że następuje transfer kwestii pomiędzy subagendami medialnymi. Powodem tego transferu jest przede wszystkim stosowanie standardowych kryteriów newsa przez dziennikarzy, a jego skutkiem zawężenie obrazu przedstawianego świata do problemów i wydarzeń o wysokiej wartości informacyjnej, ale nie zawsze, a nawet relatywnie rzadko, o wysokiej istotności społecznej. Potwierdzona została także częściowo hipoteza druga, dotycząca transferu kwestii z agendy czynników świata rzeczywistego do agendy medialnej, który to transfer, w badanym okresie, występuje w stopniu istotnym tylko w zakresie niektórych kwestii, a analiza jakościowa wskazuje na odmienny przedmiot tych kwestii w agendzie medialnej i rzeczywistej. Przyczyną tego stanu jest odmienna od natury świata rzeczywistego właściwość agendy medialnej determinowana komercjalizacją przekazu (zarówno prasy, jak telewizji, prywatnej i publicznej). Skutkiem stwierdzonej niespójności jest brak relewantnego odzwierciedlenia problemów świata rzeczywistego w agendzie intermedialnej. Do rozważenia pozostaje problem, czy skrzywianie obrazu świata następuje w sposób nieświadomy, czy jest działaniem celowym (manipulowanie uwagą opinii publicznej) stosowanym przez nadawców medialnych (oraz w jakim zakresie). Przyjmując ostrożniejszą wersję tej kwestii, można zapewne mówić o tendencyjności mediów informacyjnych poprzez upodabnianie subagend medialnych i niezapewnianie dostępu do zróżnicowanego, pełnego zestawu informacji. Do manipulowania uwagą opinii publicznej może dochodzić poprzez nadmierne eksponowanie jednych tematów, a pomijanie innych. Występuje bowiem marginalizowanie niektórych kwestii o doniosłym społecznym znaczeniu (opieka społeczna i problemy rodzin; problemy gospodarcze i ekologiczne). Inne kwestie o doniosłym społecznym znaczeniu nie są relacjonowane adekwatnie do ich ważności (zatrudnienie i praca, migracje, problemy gospodarcze). Natomiast nadmiernie eksponowane są tematy, które mają relatywnie mniejsze społeczne znaczenie (np. przestępstwa, sprawy sądowe, personalne, sport) biorąc pod uwagę wskaźniki świata rzeczywistego. Konsekwencje ustanawiania agendy intermedialnej w sposób nieadekwatny w stosunku do agendy „,rzeczywistej” ma szczególne znaczenie podczas kampanii wyborczej, kiedy 
obywatele podejmują decyzje polityczne na podstawie informacji uzyskanych z mediów. Nieadekwatność agendy medialnej w sposób pośredni prowadzi więc do nieadekwatności decyzji wyborczych w stosunków do stanu świata rzeczywistego. Należy jednakże wyraźnie zaznaczyć, że wnioski te zostały sformułowane na podstawie ograniczonego czasowo zestawu danych i moga być bezpośrednio odnoszone tylko do wybranego okresu i materiału badawczego. Wydaje się jednak, że wskazują one na pewne wyraźne tendencje, które mogą być potwierdzone w dalszych studiach poświęconych interakcji agendy intermedialnej i agendy czynników świata rzeczywistego.

\section{Bibliografia}

Birkland T. (2007), After Disaster: Agenda Setting, Public Policy and Focusing Event, Georgetown University Press, Washington.

Comparative Agendas Project, http://www.comparativeagendas.info/?page_id=101, 30.12.2014.

Danielian L. H., Reese S. D. (2009), A Closer Look at Intermedia Influences on Agenda Setting: The Cocaine Issue of 1986, w: Communication Campaigns About Drugs. Government, Media and the Public, red. P. Shoemaker, Routledge, Mahwah.

Dearing J. W., Rogers E. M. (1988), Agenda-setting research: Where has it Been? Where is it going?, w: J. A. Anderson, Communication Yearbook 11, Sage, Newbury Park.

Dearing J. W., Rogers E. M. (1996), Agenda-Setting. Communication Concepts 6, Sage, Thousand Oaks-London-New Delhi.

Funkhouser G. R. (1973), The Issues of the Sixties; An Exploratory Study in the Dynamics of Public Opinion, Public Opinion Quarterly, vol. 37, nr 1.

Funkhouser G. R., Shaw E. F. (1990), How Synthetic Experience Shapes Social Reality, ,Journal of Communication”, vol. 40.

Galtung J., Ruge M. H. (1965), The Structure of Foreign News. The Presentation of the Congo, Cuba and Cyprus Crises in Four Norwegian Newspapaers, „Journal of Peace Research", vol. 2, nr 1.

Gava R., Giugni M., Varone F. (2013), The Impact of Social Movements on Agenda-setting: Bringing the Real World Back In, w: Between-Election Democracy: The Representative Relationship After Election Day, red. P. Esaiasson, H. M. Narud, ECPR Press, Colchetser.

Golan G. (2006), Inter-media Agenda Setting and Global News Coverage. Assesing the influence of the New York Times on three network television evening news programs, „Journalism Studies”, vol. 7, nr 2. 
Herman E. S., Chomsky N. (1988), Mnaufacturing Consent. The Political Economy of the Mass Media, Pantheon Books, New York.

Jones B. D., Baumgartner F. R. (2005), The Politics of Attention. How Government Prioritizes Problems, Chicago University Press, Chicago.

Kingdon J. W. (1984), Agendas, Alternatives, and Public Policies, Little, Brown, Boston.

Lisowska-Magdziarz M. (2014), Władza24. Dziennikarz informacyjny w świecie polityki zmediatyzowanej, ,e-Politikon”, nr XII.

McCombs M. (2008), Ustanawianie agendy. Media masowe i opinia publiczna, Wydawnictwo Uniwersytetu Jagiellońskiego, Kraków.

McCombs M. (2014), Setting the Agenda: Mass Media and Public Opinion, 2nd Edition, Polity Press, Cambridge.

Minister Mateusz Szczurek: możliwy jest deficyt finansów publicznych poniżej 3 proc. $P K B$, (PAP),,wGospodarce.pl”, http://wgospodarce.pl/biezace-analizy/17811minister-mateusz-szczurek-mozliwy-jest-deficyt-finansow-publicznych-ponizej-3-proc-pkb, 1.01.2015.

OECD Economic Surveys: Poland 2014, Assesment and Recomendations, OECD 2014, http://www.keepeek.com/Digital-Asset-Management/oecd/economics/ oecd-economic-surveys-poland-2014/assessment-and-recommendations eco_surveys-pol-2014-3-en\#page9, 18.10.2014.

Protess D., McCombs M. (1991), Agenda setting: readings on media, public opinion and policymaking, Lawrence Erlbaum, Hillsdale.

Raport Press-Service Monitoring Mediów Spółka z o. o. „Cztery Stacje” - Tematy ogólne i tematy szczegółowe w latach 2009-2011 (raport udostępniony przez Press-Service Monitoring Mediów Spółka z o. o., w posiadaniu autorki).

Roberts M., McCombs M. (1994), Agenda Setting and Political Advertising: origins of the news agenda, „Political Communication”, vol. 11.

Rogers E. M., Chang S. (1991), Risky Business, Greenwood Publishing Group, Wesport.

Schulz W. (2006), Komunikacja polityczna. Koncepcje teoretyczne i wyniki badań empirycznych na temat mediów masowych w polityce, Wydawnictwo Uniwersytetu Jagiellońskiego, Kraków.

Sejm przyjąt budżet na rok 2015, Ministerstwo Finansów, http://www.mf.gov.pl/ ministerstwo-finansow/wiadomosci/komunikaty/-/asset_publisher/6Wwm/ content/sejm-przyjal-budzet-na-rok-2015?redirect=http $\% 3 \mathrm{~A} \% 2 \mathrm{~F} \% 2 \mathrm{Fwww}$. mf.gov.pl\%2Fministerstwo-finansow $\% 2$ Fwiadomosci $\% 2$ Fkomunikaty$\% 3 F p \_p \_i d \% 3 D 101 \_I N S T A N C E \_6 W w m \% 26 p \_p \_l i f e c y c l e \% 3 D 0 \% 26 p \_p \_$ state\%3Dnormal\%26p_p_mode $\% 3$ Dview\%26p_p_col_id $\% 3$ Dcolumn$2 \% 26 p \_p \_c o l \_c o u n t \% 3 D 1 \% 26 \_101$ INSTANCE_6Wwm_advancedSearch\%3Dfalse\%26_101_INSTANCE_6Wwm_keywords\%3D\%26_101_INSTANCE_6Wwm_delta\%3D5\%26_101_INSTANCE_6Wwm_cur\% 3D2\%26_101_INSTANCE_6Wwm_andOperator\%3Dtrue\#p_p_id_101_INSTANCE_6Wwm_, 1.01.2015. 
Soroka S. N. (2002), Agenda-setting dynamics in Canada, UBC Press, Vancouver.

Sweetser K. D., Golan G. J., Wanta W. (2008), Intermedia Agenda Setting in Television, Advertising, and Blogs During the 2004 Election, „Mass Communication \& Society", vol. 11.

Ustawa z 29 grudnia 1992 r. o radiofonii i telewizji, tekst ujednolicony, Dz. U. 2011, $\mathrm{Nr} 43$, poz. 226.

Ustawa z dnia 26 stycznia 1984 r. Prawo prasowe, Dz. U. 1984, Nr 5, poz. 24.

Vliegenthart R., Walgrave S. (2008), The Contingency of Intermedia Agenda Setting. A Longitudinal Study in Belgium, „Journalism and Mass Communication Quarterly", vol. 85, nr 4.

Walgrave S., Vliegenthart R. (2012), The Complex Agenda-Setting Power of Protest. Demonstrations, Media, Parliament, Government, and Legislation in Belgium, 1993-2000, „Mobilization”, vol. 17, nr 2.

\section{Intermedia agenda and the 'real' agenda. Inadequacy of the hierarchy of issues in the news media to the real world factors agenda during the local election campaign in 2014}

\section{Summary}

Intermedia agenda-setting is a stream of research within the agenda-setting studies which is quite new and relatively hard to find. This phenomenon is described as the transfer of salience of issues between two different media agendas (e.g. between press and TV news media agendas). The goal of the study is, firstly, to examine the press and the TV news media agendas (when the local election campaign is taking place), and their consistency, based on the agenda-setting theory and methodology. Secondly, the aim of the study is to confront the hierarchy of news in the intermedia agenda and the hierarchy of real world factors (which create the 'real' agenda, especially statistical data concerning the current public and economic importance of issues reported in the news media). The comparative analysis applied in the study is designed to determine the (in)adequacy of the salience of news (media issues), when compared to the importance of real world factors (reflecting the same problems as media issues). Consequently, the result of the research is an attempt to answer the question about the degree to which real world factors are reflected in the news media in Poland.

Key words: agenda-setting, intermedia agenda, real-world-factors agenda, news media 